\title{
Produktivitas Peralatan Konstruksi Pada Proyek Jaringan Irigasi D.I Baliase Kanan 2 (Paket IV) Kabupaten Luwu Utara
}

\author{
Daktorian Geseng Pongtimbang *1, Junus Mara ${ }^{* 2}$, Ari Kusuma $* 3$ \\ *1 Mahasiswa Program Studi Teknik Sipil, Universitas Kristen Indonesia Paulus Makassar, \\ Indonesiadaktoryan@gmail.com \\ *2,3 Dosen Program Studi Teknik Sipil, Universitas Kristen Indonesia Paulus Makassar, Indonesia \\ mara.junus@gmail.com dan Arykusuma6@gmail.com
}

Corresponding Author: daktoryan@gmail.com

\begin{abstract}
Abstrak
Penggunaan peralatan konstruksi sangat berpengaruh terhadap pekerjaan di dunia teknik sipil, dalam hal ini khususnya alat berat. Sebagai upaya peningkatan produksi pertanian di provinsi Sulawesi Selatan, kementrian Pekerjaan Umum dan Perumahan Rakyat (PUPR) semakin memperluas jaringan irigasi yang sumbernya berasal dari bendungan baliase di Kabupaten Luwu Utara. Pada pembangunan jaringan irigasi ini, proses pekerjaan masih pada tahap penghamparan dan pemadatan tanah yang menggunakan 4 alat berta yaitu Excavator, Dump Truck, Dozzer, dan Vibrator Roller. Penelitian ini dilakukan dengan metode kuantitatif dengan cara pengamatan langsung dilapangan. Pengolahan data dilakukan untuk mengetahui produktivitas dari masing-masing alat dan melihat apakah peralatan yang digunakan pada pekerjaan penghamparan dan pemadatan tanah ini sinkron. Berdasarkan hasil penelitian diketahui produktivitas Excavator sebesar 631,299 $\mathrm{m}^{3} / \mathrm{jam}$, DumpTruck sebesar 335,69 $\mathrm{m}^{3} / \mathrm{jam}$, Dozer $603,405 \mathrm{~m}^{3} / \mathrm{jam}$, dan Vibrator Roller $4987,5511 \mathrm{~m}^{3} / \mathrm{jam}$. Dari hasil dapat dilihat bahwa produktivitas pada peralatan yang digunakan tidak sinkron yang mengakibatkan terjadinya Idle Time pada beberapa alat, oleh karena itu dilakukan perhitungan sinkronisasi alat . Dari hasil perhitungan didapatkan bahwa terjadi penambahan alat pada Dump Truck sebanyak 10 unit agar mengurangi idle time pada peralatan konstruksi.
\end{abstract}

\section{Kata kunci : Peralatan konstruksi, Produktivitas, Sinkronisasi, Irigasi Baliase}

\begin{abstract}
The use of construction equipment is very influential on the work in the world of civil engineering, in this case especially heavy equipment. As an effort to increase agricultural production in South Sulawesi province, the Ministry of Public Works and Public Housing $(P U P R)$ further expanded the irrigation network whose source came from the baliase dam in North Luwu Regency. In the construction of this irrigation network, the work process is still at the stage of scattering and compacting the soil using 4 tools, namely Excavator, Dump Truck, Dozzer, and Vibrator Roller. This research is carried out by quantitative methods by way of direct observation on the ground. Data processing is done to find out the productivity of each tool and see if the equipment used in the soil scattering and compaction work is in sync. Based on the results of the study, excavator productivity was 631,299 $\mathrm{m}^{3} /$ hour, DumpTruck was $335.69 \mathrm{~m}^{3}$ / hour, Dozer 603,405 $\mathrm{m}^{3}$ / hour, and Vibrator Roller $4987.5511 \mathrm{~m}^{3} /$ hour. From the results it can be seen that the productivity on the equipment used is out of sync which
\end{abstract}


results in idle time on some tools, therefore the calculation of tool synchronization is carried out. From the results of calculations obtained that there is an addition of tools on dump trucks as many as 10 units to reduce idle time on construction equipment.

Keywords: Construction equipment, Productivity, Synchronization, Baliase Irrigation

\section{PENDAHULUAN}

Pesatnya konstruksi pada pembangunan nasional dan tingginya tingkat pertumbuhan, mengakibatkan tingkat kebutuhan akan bangunan seperti gedung, jalan, bendungan, dan irigasi juga meningkat pesat. Dalam hal ini, peranan penting sumber daya yang ada dalam suatu proyek harus dikendalikan dengan baik. Oleh sebab itu dibutuhkan perencanaan yang tepat pada pelaksanaan sehingga sumber daya dapat digunakan dengan maksimal.

Peralatan konstruksi memegang peranan penting khususnya alat berat, karena tampa alat berat kecepatan pembangunan tidak akan secepat yang direncanakan. Penggunaan alat-alat konstruksi sangat berpengaruh terhadap pekerjaan-pekerjaan di dunia teknik sipil, terutama peda pekerjaan-pekerjaan pembangunan gedung maupun pekerjaan konstruksi yang memang membutuhkan alat berat. Alasan mengapa alat berat sangat berpengaruh terhadap suatu pekerjaan karena sebagian besar pekerjaan pada suatu proyek merupakan pekerjaan berat sehingga produktivitas yang dihasilkan oleh alat berat akan lebih banyak dibandingkan jika menggunakan tenaga manusia. Pekerjaan berat disini diartikan sebagai pekerjaan yang jika menggunakan tenaga manusia akan membutuhkan tenaga yang banyak atau membutuhkan waktu yang lama. Contohnya pada pekerjaan tanah yang sebagian besar menggunakan alat berat dalam proses pengerjaannya. Seperti pada pekerjaan penimbunan dan pemadatan tanah mulai dari mengangkut material, memuat material, menghampar material, sampai proses pemadatan material menggunakan alat berat.

Dalam rangka peningkatan produksi hasil pertanian di provinsi Sulawesi Selatan yang merupakan lumbung pangan nasional, Kementrian Pekerjaan Umum dan Perumahan rakyat (PUPR) terus berupaya membangun cakupan jaringan irigasi yang bersumber pada bendungan baliase di Kabupaten Luwu Utara. Perluasan jaringan irigasi Bendung Baliase ini dilakukan kementrian PUPR melalui Balai Besar Wilayah Sungai Pompengan Jeneberang (BBWSPJ) Ditjen Sumber Daya Air (SDA) yang membangun jaringan irigasi baru menjadi tiga bagian, salah satunya Jaringan Irigasi D.I Baliase kanan 2 yang dalam perencanaan akan mengairi D.I seluas 5.567 hektar persawahan." (Biro Kumunikasi, PUPR.2020) [1].

Pada pekerjaan pembangunan Jaringan Irigasi D.I. Baliase Kanan 2 (Paket IV) proses pengerjaan masih pada tahap penghamparan dan pemadatan tanah pada jalur irigasi yang tentunya membutuhkan alat berat. Pada tahap ini ada empat jenis alat berat yang dioprasikan, yaitu Excavator sebagai alat angkut material, Dump Truck sebagai alat muat, Dozzer sebagai alat untuk penghamparan material, dan Vibrator Roller sebagai alat untuk memadatkan material. Penelitian ini dilakukan untuk mengetahui produktivitas alat berat Excavator, Dump Truck, Dozzer, dan Vibrator Roller pada pengerjaan penghamparan dan pemadatan material.

Produktivitas adalah output suatu produk yang berupa barang dan jasa untuk masing-masing faktor produksi yang digunakan dalam proses produksi [2]. Produktivitas ditunjukan untuk melihat efesiensi produksi dengan membandingkan input yang digunakan untuk memproduksi output. Faktor input merupakan sember daya yang ada, yang bisa berupa material atau bahan baku, tenaga kerja, mesin-mesin, serta sumber daya lainnya. Sedangkan pengukuran produktivitas adalah penilaian kuantitatif atas perubahan produktivitas. Dengan demikian, pengukuran produktivitas dapat dikembangngkan dari masing-masing komponen input secara terpisah maupun secara bersamaan. Pengukuran produktivitas mesing-masing komponen input sering disebut 
dengan produktivitas parsial yang biasa diukur dengan cara menghitung rasio output terhadap suatu input secara langsung. Sedangkan produktivitas total, mengukur seluruh input secara simultan [3].

Produktivitas alat berat adalah kemampuan alat dalam satuan waktu $\left(\mathrm{m}^{3} / \mathrm{jam}\right)$, Alat berat biasanya tersusun atas lima komponen yaitu implement, alat traksi, struktur, sumber tenaga dan transmisilnya (power train) serta system kendali [4].

Menurut Susy Fatena Rostianty, alat berat adalah faktor penting dalam suatu proyek konstruksi, terlebih pada proyek konstruksi berskala besar [5]. Penggunaan alat berat bertujuan untuk memudahkan pekerjaan manusia dalam suatu proyek sehingga hasil yang telah direncanakan bisa dicapai dengan lebih mudah pada waktu yang relatif lebih singkat. Alat barat yang biasanya digunakan dalam suatu proyek konstruksi yaitu [4] :

a. Alat gali (excavator) seperti bachoe, frount shovel, clamshell.

b. Alat gusur dan penghamparan material seperti dozer, wheel dozer, whel Loader

c. Alat pengangkut seperti loader, truck dan belt.

d. Alat pemadat tanah seperti compactor.

Pada penelitian ini hanya terbatas pada alat berat yang digunakan pada pekerjaan penghamparan dan peadatan material tanah. Alat yang dimaksud pada penelitian ini adalah Excavator, Dump Truck, Dozzer, dan Vibrator Roller yang digunakan pada pengerjaan Jaringan Irigasi D.I Baliase Kanan 2 (Paket IV).

Manajemen alat berat seperti pemilihan dan pengendalian alat berguna untuk merencanakan, memimpin, mengorganisir, dan melakukan pengendalian alat barat yang tujuannya untuk merealisasikan target pekerjaan yang telah direncanakan. Beberapa faktor yang harus diperhatikan saat memilih alat berat adalah sebagai berikut [6] :

a. Fungsi alat. Alat berat dikelmpokan menjadi beberapa bagian yang didasarkan pada fungsinya seperti mengangkut, menggali, menghapar, meratakan, dan memadatkan.

b. Kapasitas peralatan. Pemilihan alat berat berdasarkan volume total atau berat material yang harus diangkut atau dikerjakan. Kapasitas alat harus sesuai dengan pekerjaan agar pekerjaan dapat diselesaikan sesuai dengan waktu yang telah ditentukan.

c. Cara oprasi. Alat berat yang dipilih berdasarkan arah horizontal maupun vertical dan jarak gerakan frekuensi gerakan serta kecepatan alat.

d. Pembatasan dari metode. Pembatasan mempengaruhi pemilihan alat berat, antara lain peraturan lalu lintas, biaya dan pembongkaran. Metode konstruksi yang dipakai dapat mengakibatkan pemilihan alat berubah.

e. Ekonomi. Selain dari biaya investasi atau biaya sewah peralatan, biaya operasi dan pemeliharaan merupakan faktor penting saat pemilihan alat berat.

f. Jenis proyek. Ada beberapa jenis proyek yang umumnya menggunakan alat berat, yaitu proyek gedung, proyek pelabuhan, proyek jalan, proyek jembatan, proyek irigasi, dan pembukaan lahan.

g. Lokasi proyek. Lokasi proyek adalah faktor penting dalam memilih alat berat. seperti pada proyek yang berada di dataran tinggi atau rendah yang memerlukan alat berbeda dengan lokasih proyek yang berada di dataran rendah.

h. Jenis dan daya dukung tanah. Jenis tanah di lokasi proyek merupakan hal yang perlu untuk diperhatikan dalam memilih alat berat yang akan digunakan. Tanah terbagi menjadi beberapa kondisi yaitu padat, lepas dan asli.

i. Kondisi lapangan. Kondisi medan yang sulit dan baik merupakan faktor yang cukup mempengaruhi pemilihan alat berat.

Selain itu ada beberapa hal yang patut diperhatikan dalam merencanakan penggunaan alat berat, yaitu :

a. Volume pekerjaan yang harus diselesaikan dalam kurun waktu tertentu. 
b. Volume pekerjaan yang ada tersebut dan waktu yang telah ditentukan harus ditetapkan jenis dan jumlah alat berat yang diperlukan untuk menyelesaikan pekerjaan tersebut.

c. Dengan jenis dan jumlah alat berat yang tersedia, dapat ditentukan volume yang dapat diselesaikan, serta waktu yang diperlukan.

Adapun penelitian terkait atau jurnal sehingga penulis dapat memperluas teori yang akan digunakan dalam mengkaji penelitian yang akan dilakukan. Berikut beberapa penelitian sejenis yang terkait dengan penelitian yang akan dilakukan diantaranya Chourut (2020) "Perhitungan Produktivitas Alat Berat Dozer dan Vibrator Roller Pada Pekerjaan Pemadatan Tanah Di Bendungan Semantok" [7]. Berdasarkan hasil penelitian jumah alat berat Dozer dan Vibrator Roller mendapatkan penambahan alat pada setiap tipenya dengan perincian Dozer sebanyak 28 unit dan Vibrator Roller sebanyak 100 unit dengan waktu kerja 1,5 bulan. Effendi (2016), "Perhitungan Kebutuhan Alat Berat Pada Pekerjaan Tanah Proyek Pembangunan Pabrik Precast di Sentul" [8]. Berdasarkan hasil penelitian diketahui Produktivitas 1 unit Excavator didapat sebesar 74,828 $\mathrm{m}^{3} / \mathrm{jam}$, untuk 2 unit Dump Truck sebesar 60,457 m³am, 1 unit Bulldozer sebesar 1036,267 m³/jam, dan untuk 1 unit Vibro sebesar $16875 \mathrm{~m}^{3} / \mathrm{jam}$. Waktu yang didapatkan untuk menyelesaikan pekerjaan adalah 29 hari kerja. Evita, 2021, "Produktivitas Alat Berat Terhadap Pekerjaan Pemancangan Proyek Delf Apartemen Makassar" [9]. Berdasarkan hasil penelitian diketahui Produktivitas untuk alat truck Hino 41,15 ton/jam , Crawler crane sebesar 2039,59 m³/jam, dan Hidraulic Static Pile Driver 11,78 m³am. Untuk waktu pengerjaan didapatkan bahwa jika produktivitas semakin besar maka waktu kerja alat semakin kecil dan begitupun sebaliknya. Martin (2018), "Analisa Perhitungan Alat Berat Gali-Muat (Excavator) Dan Alat Angkut (Dump Truck) Pada Pekerjaan Pematangan Lahan Perumahan Recedence Jordan Sea [10]. Berdasarkan hasil penelitian produktivitas dari kedua alat berat tidak sesuai karena adanya jumlah Dump Truck yang kurang sehingga optimalisasi kedua alat hanya 1/4 kemampuan Dump Truck.'Dayanti Paserang, 2021"Produktivitas dan Waktu Oprasi Efektif Peralatan Pada Pekerjaan Pemadatan Lapisan Aspal" [3]. Berdasarkan hasil penelitian didapatkan produktivitas Tendem roller sebesar 118,95 ton dan Tire Roller sebesar 114,1 ton. Waktu pengerjaan yang didapatkan untuk menyelesaikan pekerjaan yaitu selama 34 hari. Putra, 2018."Analisa Produktivitas Kombinasi Alat Pada Pekerjaan Pemindahan Tanah Proyek Pembangunan Gedung Kuliah Fakultas Hukum UII" [11]. Berdasarkan hasil penelitian, kombinasi alat berat yang direkombinasikan untuk pekerjaan galian dan timbunan, yaitu terdiri dari 3 unit Excavator dan 15 unit Dump Truck dengan kapasitas $7 \mathrm{~m}^{3}$ dengan durasi waktu 336 jam. Wahyu (2020) "Analisa Produktivitas Alat Berat Pada Pekerjaan Galian dan Timbunan Prpyek Pembangunan Basement Di Gedung Pasca Sarjana IAIN Langsa, Aceh Timur" [12]. Dari hasil penelitian diketahui produktivitas 1 unit Excavator didapatkan sebesar 74,828 $\mathrm{m}^{3} / \mathrm{jam}, 9$ unit Dump Truck sebesar 60,457 m³/hari, dan 1 unit Whel Loader sebesar 446,135 m³/jam. Iqbal Ramdan, 2020, "Analisa Produktivitas Pemakaian Alat Berat Terhadap Biaya dan Waktu Pada Pembangunan Jalan Baru Lingkar Cipanas Kabupaten Garut” [13]. Berdasarkan hasil penelitian diketahui produktivitas Excavator PC-200 LC 2 unit sebesar 796,16 m³/hari, Bulldozer tipe KOMATSU-D6SP 1 unit sebesar 1073,84 $\mathrm{m}^{3} /$ hari, dan Dump Truck tipe HINO sebesar 495,36 $\mathrm{m}^{3} / \mathrm{jam}$. Dari hasil analisa terjadi percepatan proyek dengan durasi waktu penyelesaian 182 hari atau 26 bulan. Wulandari, 2017,"Analisa Produktivitas Alat Berat Pada Pekerjaan Pengerukan Di Proyek Java Intergrated Ports And State (JIPE) Di Gresik Jawa Timur [14]. Berdasarkan hasil penelitian untuk menyelesaikan pekerjaan urugan dan pemadatan dalam waktu 10 tahun membutuhkan 152 unit Dump Truck, 9 unit Dozer, dan 1 unit Vibrator Roller." 


\section{METODOLOGI}

\section{Gambaran Umum dan Lokasi Proyek}

Penelitian dilakukan selama \pm 1 minggu dan penelitian ini dilakukan pada proyek Pembangunan Jaringan Irigasi Baliase Kanan 2 (Paket IV). Proyek ini berada di Kec. Masamba Mappa' De.Eng Sukamaju Baebunta dan Malangke.

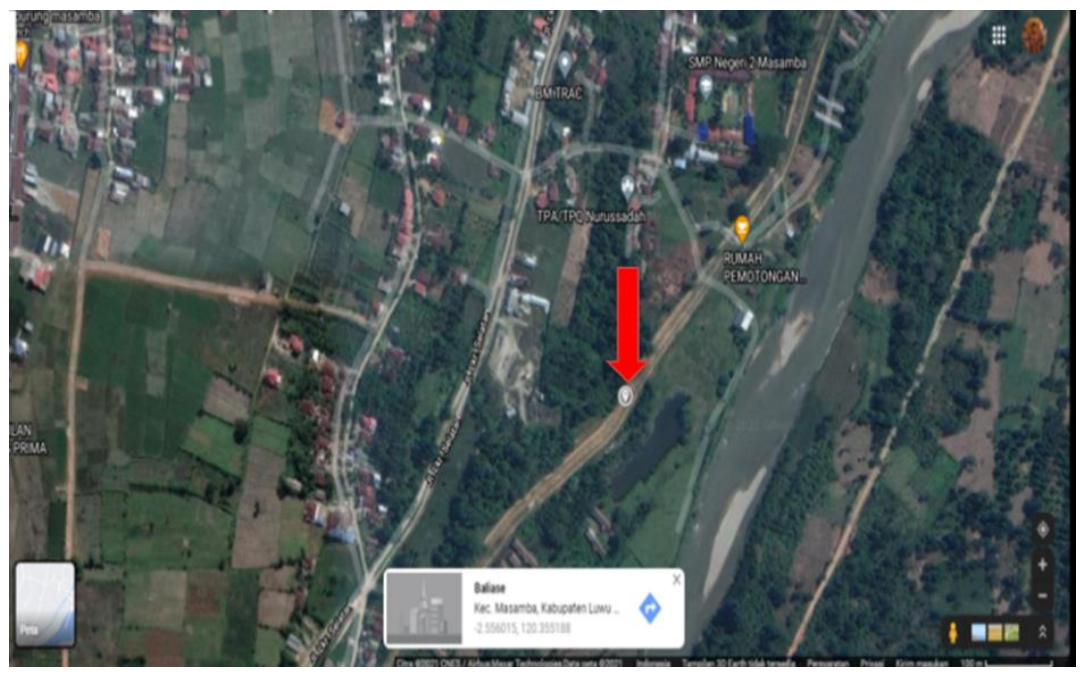

Gambar 1. Lokasi Penelitian

\section{Metode Penelitian}

Metode yang digunakan untuk penelitian ini adalah metode penelitian kuantitatif yaitu penelitian yang menuntut penggunaan banyak angka, mulai dari pengumpulan data sampai penampilan hasil yang biasanya disertai dengan gambar, tabel, dan grafik. Penelitian kuantitatif bersifat terstruktur atau berpola. Pengamatan dilakukan dengan mengamati pekerjaan peralatan dengan menghitung produktivitas serta memperhatikan faktor-faktor yang mempengaruhi produktivitas.

\section{Pengolahan Data}

Pengolahan data dilakukan dengan memasukan data yang telah diperoleh dari lokasi penelitian ke dalam tabel yang telah dibuat, lalu dilakukan perhitungan dengan memasukan rumus yang digunakan untuk mendapatkan kapasitas produksi alat, dimana perhitungan dilakukan dengan menghitung kapasitas peralatan yang digunakan pada proyek dengan mencari waktu siklus per jam, dan mencari kapasitas produksi alat.

\section{ANALISA DAN PEMBAHASAN}

\section{Volume Pemadatan Tanah}

Dari data yang diperoleh pembangunan jaringan irigasi dibagi atas 13 ruas dimana dari 13 ruas yang akan ditimbun dan dipadatkan sudah ada 6 ruas yang telah selesai dikerjakan. Untuk ruas yang masih dalam tahap pekerjaan itu masih ada 7 ruas yaitu ruas $4,5,9,10,11,12$, dan 13. Berikut data dan total volume yang dinyatakan dalam satuan padat yang masih akan dikerjakan. 
Tabel 1. Volume Pemadatan Tanah

\begin{tabular}{ccccccc}
\hline \multirow{2}{*}{ Ruas } & \multirow{2}{*}{ Stasiun } & $\mathbf{P}$ & $\mathbf{L a}$ & $\mathbf{L b}$ & $\mathbf{t}$ & $\mathbf{v}$ \\
\cline { 3 - 7 } & & $\mathbf{m}$ & $\mathbf{m}$ & $\mathbf{m}$ & $\mathbf{m}$ & $\mathbf{m 3 ( C M )}$ \\
\hline 4 & STA 2+000 - STA 2+765 & 1575 & 11.8 & 15.64 & 1.56 & 33710.04 \\
\hline 5 & STA 2+765 - STA 3+724 & 985 & 11.8 & 15.5 & 1.54 & 20705.685 \\
\hline 9 & STA 6+758 - STA 7+145 & 415 & 8.9 & 14.24 & 1.28 & 6145.984 \\
\hline 10 & STA 7+145 - STA 8+007 & 879 & 7.89 & 10.34 & 1.12 & 8973.5352 \\
\hline 11 & STA 8+007 - STA 8+995 & 985.5 & 7.03 & 9.5 & 0.94 & 7656.44805 \\
\hline 12 & STA 8+995 - STA 9+562 & 600.5 & 7 & 9.3 & 0.9 & 4404.6675 \\
\hline 13 & STA 9+562 - STA 10+357 & 818.5 & 6 & 8.25 & 0.81 & 4723.76813 \\
\hline \multicolumn{7}{c}{ TOTAL VOLUME } \\
\hline \multicolumn{7}{c}{}
\end{tabular}

\section{Analisa Data Pekerjaan}

\section{a. Analisa Data Excavator}

$\begin{array}{ll}\text { - } \quad \text { Kondisi alat } & =\text { Baik } \\ \text { - } \quad \text { Kapasitas bucket (ql) } & =1 \mathrm{~m}^{3} \\ \text { - } \quad \text { Faktor bucket }(\mathrm{K}) & =0.9 \\ \text { - Jenis tanah } & =\text { Tanah biasa } \\ \text { - } \quad \text { Efisiensi Kerja (E) } & =0,75\end{array}$

Tabel 2. Data Pengamatan Excavator

\begin{tabular}{cccc}
\hline Hari & $\begin{array}{c}\text { Waktu Gali } \\
\text { (dtk) }\end{array}$ & $\begin{array}{c}\text { Waktu Putar } \\
\text { (dtk) }\end{array}$ & $\begin{array}{c}\text { Waktu Buang } \\
\text { (dtk) }\end{array}$ \\
\hline 1 & 9 & 10 & 5 \\
\hline 2 & 9.5 & 10 & 5.2 \\
\hline 3 & 9.2 & 10 & 5 \\
\hline 4 & 9 & 10 & 5.3 \\
\hline 5 & 9 & 10 & 5 \\
\hline 6 & 9 & 10 & 5.3 \\
\hline Rata-rata & 9.12 & 10 & 5.13 \\
\hline
\end{tabular}

Hasil perhitungan :

Produktivitas $(\mathrm{P})$

$$
\mathrm{P}=\frac{\mathrm{q} \times 3600 \times \mathrm{E}}{\mathrm{Cm}}
$$

Produksi/siklus

$$
\begin{aligned}
\mathrm{q} & =\mathrm{ql} \times \mathrm{K} \\
& =1 \times 0,9=0,9 \mathrm{~m}^{3}
\end{aligned}
$$

Waktu siklus

$$
\begin{aligned}
\mathrm{Cm} & =\text { Waktu gali }+ \text { Waktu putar } \mathrm{x} 2+\text { Waktu buang } \\
& =9,175+10+5,075 \\
& =24,25 \text { detik }
\end{aligned}
$$




$$
\begin{aligned}
\mathrm{P} & =\frac{\mathrm{q} \times 3600 \times \mathrm{E}}{\mathrm{Cm}} \\
& =\frac{0,9 \times 3600 \times 0,75}{24,25}=100,206 \mathrm{~m}^{3} / \mathrm{jam}
\end{aligned}
$$

Produksi/hari

$=$ Produktivitas/jam $\mathrm{x}$ jam kerja

$=100,206 \mathrm{~m}^{3} / \mathrm{jam} \times 7 \mathrm{jam}=701,443 \mathrm{~m}^{3} / \mathrm{hari}(\mathrm{LM})=631,299 \mathrm{~m}^{3} / \mathrm{hari}(\mathrm{CM})$

\section{b. Analisa Data Alat Muat Dump Truck}

- Kondisi alat = Baik

- Kapasitas bucket (ql) $\quad=1 \mathrm{~m}^{3}$

- Faktor bucket $(\mathrm{K}) \quad=0,9$

- Jarak angkut (D) $\quad=30 \mathrm{~km}$

- Efisiensi Kerja (E) $\quad=0,71$

- Kecepatan bermuatan (V1) $=30 \mathrm{~km} / \mathrm{jam}$

- Kecepatan kosong (V2) $=40 \mathrm{~km} / \mathrm{jam}$

Tabel 3. Data Pengamatan Dump Truck

\begin{tabular}{cccc}
\hline Pengamatan & $\begin{array}{c}\text { M } \\
\text { Jumlah ret } \\
\text { Unit }\end{array}$ & $\begin{array}{c}\text { t1 } \\
\text { Waktu buang } \\
\text { Jam }\end{array}$ & $\begin{array}{c}\text { t2 } \\
\text { Waktu muat } \\
\text { Jam }\end{array}$ \\
\hline 1 & & 0.025 & 0.038333 \\
2 & 20 & 0.0167 & 0.0333333 \\
3 & & 0.0333333 & 0.04 \\
4 & & 0.025 & 0.0333333 \\
\hline Rata-rata & 20 & 0.025 & 0.036 \\
\hline
\end{tabular}

Hasil perhitugan :

Produktivitas /jam (P)

$$
P=\frac{q \times E}{C m} \times M
$$

Jumlah siklus muat

$$
\begin{aligned}
\mathrm{n} & =\frac{\mathrm{cl}}{\mathrm{ql \times K}} \\
& =\frac{7}{1 \times 0,9}=7,78=8
\end{aligned}
$$

Produksi/siklus

$$
\begin{aligned}
\mathrm{q} & =\mathrm{n} \times \mathrm{q} \mathrm{l} \times \mathrm{K} \\
& =8 \times 1 \times 0,9=7 \mathrm{~m}^{3}(\mathrm{LM})
\end{aligned}
$$

Waktu siklus

$$
\begin{aligned}
\mathrm{Cmt} & =\frac{\mathrm{D}}{\mathrm{V} 1}+\frac{\mathrm{D}}{\mathrm{V} 2}+\mathrm{t} 1+\mathrm{t} 2 \\
& =\frac{30}{30}+\frac{30}{40}+0,025+0,036=1,865 \mathrm{Jam} \\
\mathrm{P}= & \frac{\mathrm{q} \times \mathrm{E}}{\mathrm{Cm}} \times \mathrm{M}
\end{aligned}
$$




$$
=\frac{7 \times 0,71}{1,865} \times 20=53,284 \mathrm{~m}^{3} / \mathrm{jam}(\mathrm{LM})
$$

Produksivitas/hari

$=$ Produktivitas/jam $\mathrm{x}$ jam kerja

$=53,284 \mathrm{~m}^{3} / \mathrm{jam} \times 7 \mathrm{jam}$

$=372,988 \mathrm{~m}^{3} /$ hari $(\mathrm{LM})=335,69 \mathrm{~m}^{3} /$ hari $(\mathrm{CM})$

Untuk produktivitas per ret :

$$
=\frac{335,69}{20}=16,784 \mathrm{~m}^{3} / \text { hari }(\mathrm{CM})
$$

\section{c. Analisa Data Alat Penghampar Dozer}

- Kondisi alat

- Jenis tanah

- Faktor blade (a)

- Lebar blade (L)

- Tinggi blade $(\mathrm{H})$

- Efisiensi Kerja (E)
$=$ Baik

$=$ Tanah biasa

$=0,9$

$=3,73 \mathrm{~m}$

$=1 \mathrm{~m}$

$=0,75$

Tabel 4. Data Pengamatan Dozer

\begin{tabular}{ccccc}
\hline \multirow{2}{*}{ Pengamatan } & $\mathbf{D}$ & $\mathbf{F}$ & $\mathbf{R}$ & $\mathbf{Z}$ \\
\cline { 2 - 5 } & Jarak $(\mathbf{m})$ & $\begin{array}{c}\text { Kec maju } \\
(\mathbf{m} / \mathbf{m n t})\end{array}$ & $\begin{array}{c}\text { Kec mundur } \\
(\mathbf{m} / \mathbf{m n t})\end{array}$ & $\begin{array}{c}\text { Waktu ganti gigi } \\
(\mathbf{m n t})\end{array}$ \\
\hline 1 & 25 & 83.33 & 116.67 & 0.7 \\
\hline 2 & 25 & 83.33 & 116.67 & 0.74 \\
\hline 3 & 25 & 83.33 & 116.67 & 0.8 \\
\hline 4 & 25 & 83.33 & 116.67 & 0.75 \\
\hline Rata-rata & 25 & 83.33 & 116.67 & 0.748 \\
\hline
\end{tabular}

Hasil perhitugan :

Produktivitas /jam (P)

$$
\mathrm{P}=\frac{\mathrm{q} \times 60 \times \mathrm{E}}{\mathrm{Cm}}
$$

Produksi/siklus

$$
\begin{aligned}
\mathrm{q} & =\mathrm{L} \times \mathrm{H} \times \mathrm{a} \\
& =3,73 \times 1 \times 0,9=2.686 \mathrm{~m}^{3}(\mathrm{LM})
\end{aligned}
$$

Waktu siklus

$$
\begin{aligned}
\mathrm{Cm} & =\frac{\mathrm{D}}{\mathrm{F}}+\frac{\mathrm{D}}{\mathrm{R}}+\mathrm{Z} \\
& =\frac{25}{83,33}+\frac{25}{116,67}+0,748=1.262 \text { menit } \\
\mathrm{P} & =\frac{2,686 \times 3600 \times 0,75}{1,262}=95,778 \mathrm{~m}^{3} / \mathrm{jam}(\mathrm{LM})
\end{aligned}
$$

Produksi/hari

$=$ Produktivitas/jam $\mathrm{x}$ jam kerja

$=96,351 \mathrm{~m}^{3} / \mathrm{jam} \times 7 \mathrm{jam}=670,45 \mathrm{~m}^{3} / \mathrm{hari}(\mathrm{LM})=603,405 \mathrm{~m}^{3} / \mathrm{hari}(\mathrm{CM})$

\section{d. Analisa Data Vibrator Roller}


Penelitian untuk pemadatan dilakukan pada ruas 9 yang dibagi atas 4 lapisan. Jarak pemadatan yang dikerjakan adalah $75 \mathrm{~m}$ atau $0.075 \mathrm{~km}$ (STA 6+758 - STA 6+833)

- Kondisi alat $\quad=$ Baik

- Jenis tanah = Tanah biasa

- Lebar Roda (Le) $\quad=2,15 \mathrm{~m}$

- Lebar overlape (Lo) $=0,2 \mathrm{~m}$

- Jumlah laluan (M) $=3$

- Jarak pemadatan $(\mathrm{J})=75 \mathrm{~m}=0,075 \mathrm{~km}$

- Waktu ganti gigi $(Z)=0,1$ menit $=0,00166667$ jam

- Efisiensi Kerja (E) $\quad=0,75$

Hasil perhitugan :

Lapis 1

Taksiran produksi /jam

$\mathrm{TP}=\frac{\mathrm{V}}{\mathrm{T}}$

Jumlah trip

$$
\begin{aligned}
\mathrm{N} & =\frac{\mathrm{W}}{\mathrm{Le}-\mathrm{Lo}} \\
& =\frac{14,24}{2,15-0,2}=7,3025=8 \text { trip } \\
\mathrm{Vx} & =\frac{\mathrm{M}}{\frac{1}{\mathrm{~V} 1}+\frac{1}{\mathrm{~V} 2}+\frac{1}{V} \ldots \ldots . .} \\
& =\frac{3}{\frac{1}{4}+\frac{1}{4}+\frac{1}{6}}=5 \mathrm{~km} / \mathrm{jam} \\
& =\mathrm{M} \times\left(\frac{\mathrm{J}}{\mathrm{Vx}}+\mathrm{Z}\right) \times \mathrm{N} \times \frac{1}{\mathrm{E}} \\
& =3 \times\left(\frac{0,075}{5}+0,00166667\right) \times 8 \times \frac{1}{0,75}=0,586667 \mathrm{jam}
\end{aligned}
$$

Untuk perhitungan waktu pada lapis 2, 3, dan 4 dapat dilihat pada tabel :

Tabel 5. Data Pengamatan Vibrator Roller

\begin{tabular}{cccccccc}
\hline \multirow{2}{*}{ Lapis } & $\mathbf{W}$ & $\mathbf{V 1}$ & $\mathbf{V 2}$ & $\mathbf{V 3}$ & $\mathbf{V x}$ & $\mathbf{N}$ & $\mathbf{T}$ \\
\cline { 2 - 8 } & $\mathbf{m}$ & $\mathbf{k m}$ & $\mathbf{k m}$ & $\mathbf{k m}$ & $\mathbf{k m}$ & Streep & Jam \\
\hline 1 & 14.24 & 4 & 4 & 6 & 4.5 & 8 & 0.586667 \\
\hline 2 & 12.91 & 5 & 5 & 6 & 5.2941 & 7 & 0.443333 \\
\hline 3 & 11.57 & 6 & 6 & 8 & 6.5455 & 6 & 0.315 \\
\hline 4 & 10.24 & 8 & 8 & 9 & 8.3077 & 5 & 0.213889 \\
\hline
\end{tabular}

$$
\begin{aligned}
\mathrm{T}_{\text {total }} & =\mathrm{T}_{1}+\mathrm{T}_{2}+\mathrm{T}_{3}+\mathrm{T}_{4} \\
& =0,587+0,443333+0.315+0,214=1,558889 \mathrm{jam}
\end{aligned}
$$




$$
\begin{aligned}
\mathrm{V} & =\frac{\mathrm{La}+\mathrm{Lb}}{2} \times \mathrm{P} \times \mathrm{t} \\
& =\frac{8,9+14,24}{2} \times 75 \times 1,28=1110,72 \mathrm{~m}^{3} \\
\mathrm{TP} & =\frac{1110,72}{1,558889}=712,5073 \mathrm{~m}^{3} / \mathrm{jam}(\mathrm{CM})
\end{aligned}
$$

Taksiran Produksi / hari

$$
\begin{aligned}
& =\mathrm{TP} \times 7 \mathrm{jam} \\
& =712,5073 \mathrm{~m}^{3} / \mathrm{jam} \times 7 \mathrm{jam}=4987,5511 \mathrm{~m}^{3} / \text { hari }(\mathrm{CM})
\end{aligned}
$$

\section{Waktu Kerja}

Waktu kerja yang dihasilakan dari masing-masing alat adalah sebagai berikut :

\section{Excavator}

Kapasitas produksi Excavator per hari yaitu sebesar $631,299 \mathrm{~m}^{3} /$ hari dan besar volume pekerjaan adalah $86320,13 \mathrm{~m}^{3}$, maka waktu pekerjaan yaitu :

Waktu Pekerjaan $=\frac{86320,13}{631,299}=136,374$ hari, dibulatkan 137 hari

\section{Dump Truck}

Kapasitas produksi Dump Truck per hari yaitu sebesar 319,011 $\mathrm{m}^{3} /$ hari dan besar volume pekerjaan adalah $86320,13 \mathrm{~m}^{3}$, maka waktu pekerjaan yaitu :

Waktu Pekerjaan $=\frac{86320,13}{335,69}=257,142$ hari, dibulatkan 258 hari

\section{Dozer}

Kapasitas produksi Dozer per hari yaitu sebesar $607,013 \mathrm{~m}^{3} / \mathrm{hari}$ dan besar volume pekerjaan adalah $86320,13 \mathrm{~m}^{3}$, maka waktu pekerjaan yaitu

$$
\text { Waktu Pekerjaan }=\frac{86320.13}{603,405}=143,055 \text { hari dibulatkan } 144 \text { hari }
$$

\section{Vibrator Roller}

Kapasitas produksi Vibrator Roller per hari yaitu sebesar 4987,5511 $\mathrm{m}^{3} /$ hari dan besar volume pekerjaan adalah $86320,13 \mathrm{~m}^{3}$, maka waktu pekerjaan yaitu :

$$
\text { Waktu Pekerjaan }=\frac{86320,13}{4987,5511}=17,307 \text { hari, dibulatka Hari }
$$

\section{Sinkronisasi Peralatan}

Perhtiungan sinkronisasi dilakukan pada alat berat yang berhubungan langsung. Pada proyek ini perhitungan sinkronisasi dilakukan pada peralatan Excavator dan Dump Truck. Perhitungan sinkronisasi ini juga dilakukan karena produktivitas Dump Truck tidak sinkron dengan produktivitas Excavato sehingga menghasilkan Idle time. Berikut perhitungan yang dilakukan :

n.Dump Truck $=\frac{631,299}{16,784}$ (Digunakan produk Truc /ret) $=37,631$, dibulatkan 40 ret

Penjabaran = Dalam 1 hari dioprasikan 5 unit Dump Truck, 1 unit Itu bisa sampai 4 ret, maka per hari bisa 20 ret. Jika sinkronisasinya 40 ret maka Dump Truck yang dioprasikan sebanyak 10 unit/hari $(10 \times 4=40)$ 


\section{Pembahasan}

\section{Produktivitas dan Waktu Kerja}

Dari hasil pengolahan data, diketahui Produktivitas dan Waktu kerja yang dihasilkan dari pengoprasian 1 unit Excavator, 20 ret Dump Truck, 1 unit Dozer, dan 1 unit Vibrator Roller yaitu :

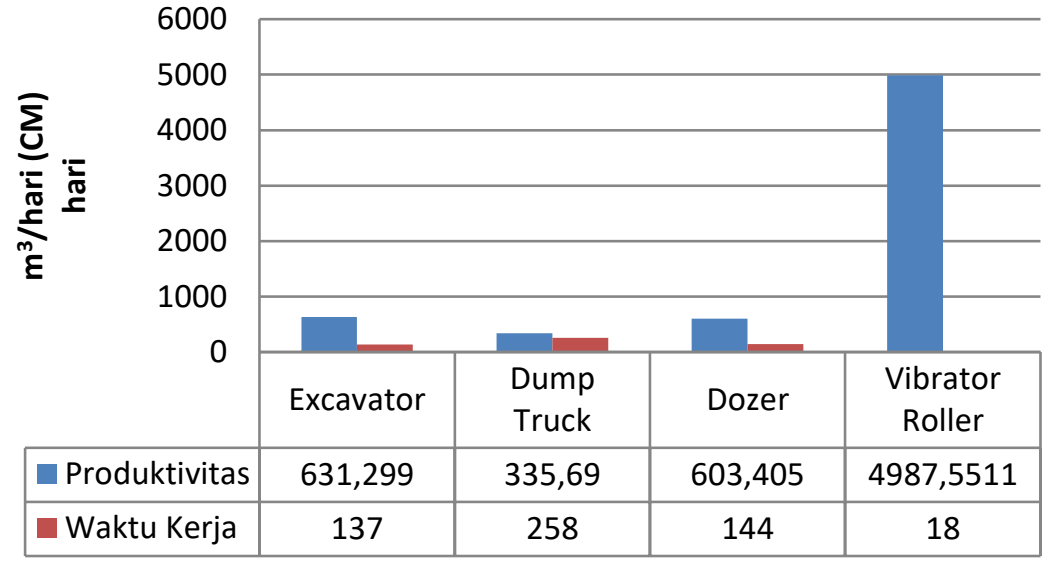

Gambar 3. Grafik Produktivitas dan Waktu kerja

Berdasarkan grafik di atas menunjukan ada perbedaan pada produktivitas dan waktu kerja, terutama pada alat Dump Truck dimana produktivitas yang dihasilkan kecil yaitu $335,69 \mathrm{~m}^{3} /$ hari sehingga mengakibatkan waktu kerja yang dibutuhkan juga semakin lama sekitar 258 hari. Permasalahan ini diakibatkan karena waktu siklus Dump Truck yang cukup lama yaitu sekitar 1,865 Jam. Hal ini disebabkan oleh jarak antara pengambilan material dan lokasi proyek yang cukup jauh sekitar $30 \mathrm{~km}$ ditambah jalan yang kurang baik dan sempit yang mengakibatkan waktu yang ditempuh dalam perjalanan cukup lama.

Begitupun juga untuk Vibrator Roller yang mempunyai produktivitas paling besar yaitu 4987,5511 $\mathrm{m}^{3} / \mathrm{hari}$ sehingga waktu kerja yang dibutuhkan juga tidak lama sekitar 18 hari. Hal ini disebabkan waktu yang dibutuhkan Vibrator Roller dalam proses pemadatan dapat dikatakan cukup cepat yaitu sekitar 1,65 jam untuk menyelesaikan pemadatan.

2. Sinkronisasi Alat

Karena produktivitas dan waktu kerja peralatan tidak sinkron, maka dilakukan perhitungan sinkronisasi peralatan sebagai berikut :

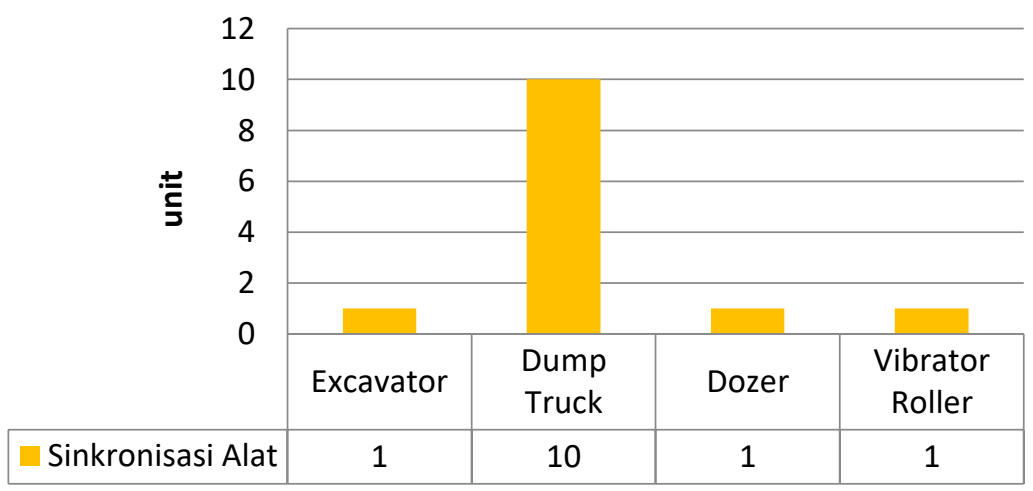




\section{Gambar 4. Grafik Sinkronisasi Peralatan}

Berdasarkan grafik, untuk 1 unit Excavator membutuhkan 10 unit Dump Truck, 1 unit Dozer, dan 1 unit Vibrator Roller untuk mengurangi Idle Time (waktu tidak beroprasi pada jam kerja).

\section{KESIMPULAN}

\section{Kesimpulan}

Berdasarkan hasil penelitian yang telah dilakukan pada proyek Pembangunan Jaringan Irigasi D.I Baliase Kanan 2 (Paket IV) Kabupaten Luwu Utara disimpulkan bahwa :

1. Produktivitas dan waktu kerja antar peralatan tidak sinkron, terutama pada alat Dump Truck yang menghasilkan produktivitas paling kecil sehingga memerlukan waktu yang cukup lama untuk menyelesaikan pekerjaan. Dump Truck berperan penting pada proses pekerjaan ini, dikarenakan produktivitas yang berada jauh di bawah peralatan yang lain, sehingga mangakibatkan terjadinya Idle Time pada peralatan yang lain.

2. Dari sinkronisasi peralatan yang telah diperhitungkan untuk meminimalkan Idle Time peralatan, diambil acuan produktivitas Excavator karena lebih efisien daripada Vibrator Roller. Alasannya jika kita mengacu pada Vibrator Roller akan banyak penambahan peralatan pada setiap alat, sedangkan jika kita mengacu pada Excavator penambahan peralatan hanya pada Dump Truck. Dalam hal ini percepatan waktu kerja setidaknya bisa dipercepat dari acuan awal 258 hari menjadi 137 hari.

\section{DAFTAR PUSTAKA}

[1] PUPR, Peningkatan Produksi Pertanian, Jakarta: Biro Komunikasi PUPR, 2020.

[2] S. F. Rostiyanti, Produktvitas Alat Berat Pada Proyek Konstruksi, Jakarta: Penerbit Bineka Cipta, 1999.

[3] D. Paserang, Produktivitas dan Waktu Operasi Efektif Peralatan Pada Pekerjaan Pemadatan Lapisan Aspal, Skripsi: Fakultas Teknik. Universitas Kristen Indonesia Paulus Makassar, 2021.

[4] Rochmanhadi, Alat-alat Berat dan Penggunaanya, Jakarta: Badan Penerbit Pekerjaan Umum, 1992.

[5] F. R. Rostianty, Alat Berat Untuk Proyek Konstruksi. Edisi Dua, Jakarta: Penerbit Bineka Cipta, 2008.

[6] D. Walipo, Metode Konstruksi dan Alat-alat Berat, Jakarta: Penerbit Universitas Indonesia, 2009.

[7] F. A. Chourut, "Perhitungan Produktivitas Alat Berat Dozer dan Vibrator Roller Pada Pekerjaan Pemadatan Tanah di Bendungan Semantok", Skripsi: Fakultas Teknik. Universitas Jember, 2020.

[8] D. S. H. Effendi, "Perhitungan Kebutuhan Alat Berat Pada Pekerjaan Tanah Proyek Pembangunan Pabrik Precast di Sentul", (JOM) UNPAK: Vol 1. No 1, 2016.

[9] J. Evita , Produktivitas Alat Berat Terhadap Pekerjaan Pemancangan Proyek Delf Apartemen Makassar, Skripsi: Fakultas Teknik. Universitas Kristen Indinesia Paulus Makassar, 2021.

[10] R. S. Martin, "Analisa Perhitungan Gali-Muat Excavator dan Alat Angkut Dump Truck Pada Pekerjaan Pematangan Lahan Perumahan Recedence Jordan Sea", TEKNO: Vol 16. No 70, 2018.

[11] D. H. Putra, "Analisa Produktivitas Kombinasi Alat Pada Pekerjaan Pemindahan Tanah Proyek Pembangunan Gedung Kuliah Fakultas Hukum UII", Skripsi: Fakultas Teknik Sipil dan Perancangan. Universitas Islam Indonesia, 2018. 
[12] E. T. W. Putra, "Analisa Produktivitas Alat berat Pada Pekerjaan Galian dan Timbunan Proyek Pembangunan Basement di Gedung Pasca Sarjana IAIN Langsa, Aceh Timur", Skripsi: Fakultas Teknik. Universitas Muhammadiyah Sumatra Utara, 2020.

[13] M. I. Ramdan, "Analisa Produktivitas Pemakaian alat Berat Terhadap Biaya Dan Waktu Pada Pembangunan Jalan Baru Lingkar Cipanas Kabupaten Garut", Online Journal STT-Garut: Vol 18. No 2, 2020.

[14] L. Wulandari, "Analisa Produktivitas Alat Berat Pada Pekerjaan Pengurus di Proyek Java Intergrated Ports And State (JIPE) Gersik Jawa Timur", REKATS: Vol 3. No 1, 2017.

[15] Rochmanhadi, Perhitungan Biaya Pelaksanaan Pekerjaan Dengan Menggunakan Alat-alat Berat, Jakarta: Badan Penerbit Pekerjaan Umum, 1985.

[16] A. T. Tenriajng, Pemindahan Tanah Mekanis. Seri Diklat Kuliah, Jakarta: Universitas Gunadarma, 2003.

[17] S. Chad, What Determines Productivity?, American: American Economic Association, 2011.

[18] M. A. Thayeb, "Perencanaan Alat Berat Pada Plant PT.Semen Indonesia di Balikpapan", Skripsi: Fakultas Teknik Sipil dan Perencanaan. Institut Teknologi Sepuluh Nopember Surabaya, 2015. 